\title{
Social Studies Teacher Candidates' Views on Science, Technology, and Society
}

\section{Research Article}

\section{Canan TUNC SAHIN ${ }^{1}$}

${ }^{1}$ Zonguldak Bülent Ecevit University, Faculty of Education, Department of Social Studies Education, Zonguldak, Turkey, ORCID: 0000- 00030997-2124

To cite this article: Tunc-Sahin, C. (2021). Social studies teacher candidates' views on science, technology, and society, International Online Journal of Educational Sciences, 13(4), 1045-1058.

\begin{tabular}{ll} 
ARTICLE INFO & ABSTRACT \\
\hline Article History: & $\begin{array}{l}\text { To qualify individuals in society as scientifically literate, they need to have a sufficient understanding } \\
\text { of science, technology, and the relationship of society. Educational restructuring efforts emphasize } \\
\text { scientific literacy as an important goal. The studies, in the literature, reveal that teachers and teacher } \\
\text { Received: 19.11.2020 }\end{array}$ \\
candidates have misconceptions about science and technology and there is an important lack of \\
knowledge about the effects of science and technology on society. This study aims to determine the \\
ofinions of social studies teacher candidates about science, technology, and the impact of science and \\
technology on society. A semi-structured interview technique was used in this study, designed as a \\
case study, among qualitative research methods. The study was carried out with 10 social studies \\
teacher candidates who took the Science-Technology and Social Change course at a university in the \\
Western Black Sea region in 2018. The themes reached in the analysis process were grouped under \\
three dimensions: science, technology, and the relationship of society with science and technology. \\
The results obtained from the study show that teacher candidates have misconceptions about science, \\
that they confuse the concepts of science and technology, and that science and technology studies are \\
affected by the social structure of the society.
\end{tabular}

(C) 2021 IOJES. All rights reserved

Keywords:

Social studies teacher candidates, Science, Technology, Society, Scientific literacy.

\section{Introduction}

In times of rapid social changes, sociologists try to explain this change and question its source. Society has effects on science and technology, and science and technology on society. This effect also causes social change. Science and technology are improving day by day, considering the needs of society. At the same time, it gains a new shape by being influenced by scientific and technological developments in social norms.

${ }^{1}$ Corresponding author's address: Zonguldak Bülent Ecevit Üniversitesi

Telephone: +905322479047

e-mail: canantuncsahin@gmail.com

DOI: https://doi.org/10.15345/iojes.2021.04.007 
Science is developing every day, taking into account the needs of society. At the same time, social norms are taking on a new form, influenced by scientific developments. Developments in science and technology are an important factor that enables the development of society as well as accelerate social change (Sadler \& Zeidler, 2005). Today's society is constantly facing advancing science and technology (Kolstø, 2006). Scientific advances provide many examples of how science and society interact with each other. On the one hand, in the globalizing world depending on scientific developments, science and technology are renewing themselves every day and pushing the limits of today (Ata, 2017). On the other hand, societies that are aware of this process aim to teach new generations the ways to access information by using science and technology (Özdemir, 2011; Gültekin, 2020). In this globalized world, countries are competing with each other and it is aimed to educate generations who research, study, question, and think critically (Kaymakçı, 2010). For this purpose, countries aimed to educate scientifically literate individuals to bring all citizens in society to a level that will adapt to scientific and technological developments (American Association for the Advancement of Science [AAAS], 1990; Ministry of National Education [MoNE], 2014, 2016, 2019).

Scientific literacy can be defined as having the knowledge and skills necessary for an individual to make effective decisions and take responsibility for science and technology-based issues related to society (Laugsksch, 2000). For the new generation to adapt to the rapidly changing environment, it is important to create a society consisting of scientifically literate individuals within the modern education system (Çepni, Ayvac1, \& Bacanak, 2009). A society consisting of individuals who grow up to be scientifically literate will increasingly demand a higher level, more qualified, and efficient manpower (Jan 2017; Gültekin, 2020). Scientifically literate society will be achieved by raising scientifically literate individuals, expanding education, and raising the level of education. (Çepni \& Bacanak, 2002). Therefore, education has important responsibilities.

Education restructuring efforts, which have been going on for many years at the international level, emphasize scientific literacy as an important goal for the educational process (AAAS, 1989, 1990; National Research Council [NRC], 1996; 2004; National Council for the Social Studies [NCSS], 2010). As a result of taking into account the international studies, which have reflections on the Turkish education system, restructuring studies have also started in our country. In this structuring initiative, educating scientifically literate individuals has been identified as an important goal (MoNE, 2004; 2016; 2019; Çakıc1, 2012).

Many definitions of scientific literacy have been made in the literature (AAAS, 1989; National Science Teachers Association [NSTA], 1991; National Science Education Standards [NSES], 1996; Bybee, 1997; Holbrook \& Rannikmae, 1997; Hurd, 2000; Laugksch, 2000; Organisation for Economic Co-operation and Development [OECD], 2003; 2007). The main aim of the emphasis on scientific literacy is to educate individuals who know and understand the natural world, who can use appropriate scientific processes and methods in personal decisions, who can engage in discussions on scientific and technological issues (NRC, 1996; NCSS, 2004; MoNE, 2006). Science-Technology-Society (STS) is an important dimension of scientific literacy. It is important to understand how science and technology are affecting society or influenced by society (Hurd, 2000). This dimension is important for scientifically literate individuals to examine more comprehensively and make more informed decisions while making decisions on scientific or technological issues of interest to society (Kılıç, Haymana, \& Bozyılmaz, 2008; Jan 2017; Benzer, 2020). With the reform movements in education, one of the themes of the social studies course has been determined as "Science-Technology-Society" (NCSS, 2010; MoNE, 2016; MoNE, 2019). It is important to have social studies teachers who are aware of the relationship between science-technology-society for students to understand science-technology-society issues. Therefore, the Science Technology and Social Change course has been included as a compulsory course in the social studies teaching program to realize the aims such as learning about the concepts of science-technologysociety and the relationship between these issues and realizing their interactions (Council of Higher Education 
[YÖK], 1997). Within the renewed social studies teacher education program, this course continues as a compulsory course with the same content as Science, Technology, and Society (YÖK, 2019). To fulfill the task of educating scientifically literate individuals, teacher candidates must have a sufficient level of knowledge about this issue (Duban, 2010; Jan 2017). Teacher candidates should be able to have ideas on issues related to science and technology, have access to scientific knowledge, understand and interpret scientific knowledge, and participate in decision-making (AAAS, 1990; NRC, 2004; NCSS, 2010; MoNE, 2016; YÖK, 2018; MoNE, 2019).

When studies in our country are examined, it is seen that teachers and teacher candidates have misconceptions about science and technology and that they have significant deficiencies in knowledge about the impact of science and technology on society. Teachers should know the relationship between science, technology, and society which are the dimensions of scientific literacy. Therefore, the awareness of the teacher candidates about the relationship between science and technology, which is the dimension of scientific literacy, is important before they enter the teaching profession. Although its social emphasis is clear in the field of social studies education, scientific literacy studies on the subject are quite a few (Şahin, 2010; Akgün, 2015; Şahin, 2017). At the same time, studies with social studies teacher candidates are limited. This study aims to fill this gap in the field by focusing on the opinions of social studies teacher candidates on "science", "technology" and "the impact of science and technology on society".

\section{Method}

This study has been designed as a case study among qualitative research methods. A case study is a detailed examination of an event, a phenomenon, or a subject (Stake, 1995).

\section{Participants}

The convenience sampling method was used to determine the participants of his research (Patton, 2005). The easiest and most convenient sample available to the researcher was selected (Creswell, 2013). The study was carried out with 10 social studies teacher candidates at a university in the Western Black Sea region in the spring semester of 2018. Teacher candidates who took the course "Science, Technology, Social Change" conducted by the researcher and agreed to participate voluntarily in the research participated in the study. Each participant was informed beforehand about the purpose of the research. Per ethical principles, the names of the participants were kept confidential and each participant was given a nickname (K1, K2 ...K10).

\section{Data collection tools}

A semi-structured interview technique was used in this study based on the qualitative study method. The semi-structured interview technique includes both explicit and open-ended questions as a mixture of structured and unstructured interview types. (Merriam, 2009). The researcher prepared a semi-structured interview form by using the researches in the literature to get the opinions of the participants about science, technology, and the effects of science and technology on society (Ryan \& Aikenhead, 1992; Lederman, AbdEl-Khalick, Bell \& Schwartz, 2002). Questions such as "What is science?", "What is technology?", "How is the relationship between science and technology with society?" Were asked to the participants. Guiding questions were also asked to enable the participants to express their thoughts more clearly. Guiding questions such as "What distinguishes science from other disciplines?", "What is an experiment?", "Is the experiment necessary for the development of scientific knowledge?" etc. were asked in addition to the question of "What is science?" to get in-depth answers from the participants. The questions were prepared by taking the opinion of an academic working in the field of social studies education and directed to two social studies teacher candidates to determine whether the questions were understandable and fit for purpose and the necessary corrections were made. After the consent of the participants was obtained, face-to-face interviews with each participant were recorded on a voice recorder. Audio recordings were transcribed and converted into text. 


\section{Data analysis}

When analyzing the data obtained in the study, sub-dimensions were created according to the questions under each dimension, and the answers of the participants were examined by the induction method according to these sub-dimensions. With this review, common statements were determined and common themes were formed by gathering the determined common statements (Miles \& Huberman, 1994). The themes reached in the analysis process were grouped under three dimensions: science, technology, and the relationship of society with science and technology (Ryan \& Aikenhead, 1992). The science was analyzed in "content of science, the purpose of science, the method in science", sub-dimensions, the technology was analyzed in "definition of technology, advantages, and disadvantages" while the relationship of society with science and technology was analyzed in "science-technology relationship, the effect of science and technology on society, society's impact on science and technology".

The records of the data used in the research were read separately by the researcher and an expert, and the codes, themes, and sub-dimensions were examined for "consensus" and "disagreement". The reliability of data analysis was examined using the formula of "Reliability = [Consensus / (Consensus + Disagreement)] $\mathrm{x}$ 100". (Miles \& Huberman, 1994). The compliance percentage was found to be $91 \%$. A compliance rate of above $70 \%$ is considered reliable for qualitative studies (Miles \& Huberman, 1994). The issues with differences of opinion were discussed and necessary arrangements were made (Creswell, 2005; 239).

\section{Findings}

\section{Views of social studies teacher candidates about Science Technology Society}

The opinions of social studies teacher candidates about science, technology, and society were examined in headings separately as views about science, views about technology, and the effects of science and technology on society.

\section{Views of social studies teacher candidates' on science}

Views of social studies teacher candidates on science were examined in the dimensions of content of science, the purpose of science, the method in science. The results obtained from the opinions of the teacher candidates according to these dimensions are presented in Table 1.

Table 1. Views of social studies teacher candidates' on science

\begin{tabular}{|c|c|c|}
\hline Theme & Category & Statements \\
\hline \multirow{11}{*}{ Science } & \multirow{4}{*}{$\begin{array}{l}\text { Content of } \\
\text { science }\end{array}$} & Fields such as history and geography are also science $(\mathrm{K} 2, \mathrm{~K} 4, \mathrm{~K} 5, \mathrm{~K} 10)$ \\
\hline & & $\begin{array}{l}\text { Proven, reproducible, practicable things are science, areas such as history, geography are } \\
\text { not science (K3) }\end{array}$ \\
\hline & & Science is knowledge, information that develops $(\mathrm{K} 1, \mathrm{~K} 2, \mathrm{~K} 6)$ \\
\hline & & Science is the work done for the benefit of mankind to make life easier $(K 2, K 7, K 10)$ \\
\hline & \multirow{3}{*}{$\begin{array}{l}\text { Purpose of } \\
\text { science }\end{array}$} & To make life easier, for the benefit of humanity, society, for a better life $(K 3, K 4, K 8, K 9)$ \\
\hline & & $\begin{array}{l}\text { It does not always give beneficial results to humanity (example of an atomic bomb) (K1, } \\
\mathrm{K} 5, \mathrm{~K} 6, \mathrm{~K} 8, \mathrm{~K} 9, \mathrm{~K} 10)\end{array}$ \\
\hline & & Invention and technological product design (K1, K9) \\
\hline & \multirow{4}{*}{$\begin{array}{l}\text { Method in } \\
\text { science }\end{array}$} & In science, it takes experiments to prove (K1, K4, K5) \\
\hline & & $\begin{array}{l}\text { The experiment in science is not the only method, there are different methods ( } \mathrm{K} 3, \mathrm{~K} 7, \mathrm{~K} 8 \text {, } \\
\mathrm{K} 10)\end{array}$ \\
\hline & & $\begin{array}{l}\text { Scientists follow the scientific method (hypothesis building - testing - data collection - data } \\
\text { analysis, interpretation of findings - conclusion) when conducting research (K8) }\end{array}$ \\
\hline & & The scientific method differs according to the field (K4, K5, K6, K10). \\
\hline
\end{tabular}


It has been observed that there were teacher candidates who accept fields such as history and geography related to the content of science as branches of science, as well as teacher candidates who do not accept these fields as branches of science. K7, who considers history and geography as the fields of science, in regards to the content of science, stated that "Everything that can be studied, seen, measured is science. History is also science, but it is not studied, the evidence that exists is used". Teacher candidates stated that they do not accept the fields of history and geography as a science field because of the difficulty of proving these areas. I don't think K5 can answer some of the questions of "history. "I don't think you can answer some of the questions of history. Unrepeatable events are difficult to prove, so I don't see history as a science" which was the statement of K5, showed that there were teacher candidates who did not accept these fields as science.

Teacher candidates have defined science as knowledge that develops. They expressed the purpose of science as inventing things, designing technological products. From these statements, it can be said that candidate teachers confuse science and technology. K3, K4, K8, K9 have defined the purpose of science as "making life easier and revealing the facts." Some of the teacher candidates believe that scientific research is harmful to humanity and society. K10's "Scientific studies are not always used for good purposes. For example, the use of it as an atomic bomb "and $\mathrm{K} 6$ 's" can also be areas where science is abused. For example, scientific research that is used to make weapons, the atom bomb is the greatest example of this" supports the idea that science is not always used for good, scientific discoveries are used for malicious purposes. As mentioned in the statements of K10 and $\mathrm{K} 6$, most of the teacher candidates used the example of an atomic bomb when describing the malicious use of science.

Some teacher candidates defined science as finding new things through experiments. The statement of $\mathrm{K} 2$, who defends that experiment is a necessary method in science, is as follows: "Experiment is something that science does to prove. An experiment is required for every scientific research. It is a necessary tool for us to believe." There were also teacher candidates who believe that the experiment is not the only method in science. K8 stated that observation is also a method in science as "Experiment is not necessary for every single scientific research because sometimes scientific research can be done through observation."

Another candidate's opinion on the method of science is that scientists follow the scientific method (hypothesis building - testing - data collection - data analysis, interpretation of findings - conclusion) when conducting research. The opinion of K10 regarding the method of science, "There is a formal science-based on experiments, and social science-based on observation. For example, history studies use the documents in the archives as a method and analyze the information in these documents. The experiment is the domain of science." shows that the scientific method differs according to the field, for example, a scientist dealing with natural sciences uses the experiment and observation methods while the scientist dealing with social sciences follows a different method. Besides, in regards to the method of science, teacher candidates think that experimentation is necessary for fields of natural sciences such as physics and chemistry, but that experimentation is not necessary for areas of social sciences.

\section{Views of social studies teacher candidates' on technology}

Views of social studies teacher candidates on technology were examined in the dimensions of definition of technology, the advantages, and disadvantages of technology. According to these dimensions, the codes obtained from the opinions of the teacher candidates are presented in Table 2.

Table 2. Views of social studies teacher candidates' on technology

\begin{tabular}{cll}
\hline Theme & \multicolumn{1}{c}{ Category } & \multicolumn{1}{c}{ Statements } \\
\hline \multirow{3}{*}{ Technology } & Definition of technology $y$ & It is similar to science, it is the application of science \\
\cline { 3 - 3 } & & $(\mathrm{K} 6, \mathrm{~K} 7, \mathrm{~K} 8, \mathrm{~K} 9)$ \\
\hline
\end{tabular}




\begin{tabular}{|c|c|}
\hline & $(\mathrm{K} 3, \mathrm{~K} 10)$ \\
\hline & $\begin{array}{l}\text { To invent, design, discover new inventions. } \\
(\mathrm{K} 5, \mathrm{~K} 7)\end{array}$ \\
\hline \multirow{2}{*}{ Advantages } & $\begin{array}{l}\text { Makes human life easier } \\
\text { (K1,K2,K3,K4,K5,K6,K7, K8,K9,K10) }\end{array}$ \\
\hline & $\begin{array}{l}\text { Tools that facilitate daily life } \\
(\mathrm{K} 4, \mathrm{~K} 5, \mathrm{~K} 7, \mathrm{~K} 10)\end{array}$ \\
\hline \multirow{2}{*}{ Disadvantages } & $\begin{array}{l}\text { Affect the health adversely } \\
(\mathrm{K} 1, \mathrm{~K} 3, \mathrm{~K} 4, \mathrm{~K} 5, \mathrm{~K} 7, \mathrm{~K} 10)\end{array}$ \\
\hline & $\begin{array}{l}\text { Computers, cars, machines harm health } \\
\text { (K3) }\end{array}$ \\
\hline
\end{tabular}

We see that teacher candidates define technology as tools and electronics that make life easier. The statement of K7, "When we say technology, small things come to my mind, small things that allow you to communicate very quickly even from far away that does not take up much space. This is related to the advancement of technology, people probably can make them smaller." leads to the definition of technology as small tools. Besides, the fact that K9 and K6 use the statement "similar to science" when defining technology shows that teacher candidates consider science and technology the same. Statements such as "Technology is the tool that science uses, it is the way science is expressed" (K9), "Without technology, we cannot understand how science progresses or how it develops (K8)" regarding the definition of technology show that, they consider science and technology as two inseparable fields.

Teacher candidates stated that technology has advantages and disadvantages. All of the teacher candidates participating in the study stated that technology facilitates human life as its advantages. "The positive features of the technology are that it makes human life easier. For example, it enables people to access information more quickly." statement of K3 and "Everything, even the smallest, is at hand with the computer, there is no need for too much effort." statement of K7 might be cited as examples.

Many of the teacher candidates see the negative effects of technology on health as a disadvantage of technology. While K10 describes the negative effects of technology as "making people cumbersome and making people drift away from social life", K7's statement "harmful to health but you use technology to get rid of it" is noteworthy.

\section{Views of social studies teacher candidates on the relationship of science and technology with society}

Views of social studies teacher candidates on the relationship of science and technology with society were examined in the dimensions of the relationship between science and technology, the impact of science and technology on society, the impact of society on science and technology. According to these dimensions, the codes obtained from the opinions of the teacher candidates are presented in Table 3.

Table 3. Views of social studies teacher candidates on the relationship of science and technology with society

\begin{tabular}{|c|c|c|}
\hline Theme & Category & Statements \\
\hline \multirow{4}{*}{$\begin{array}{l}\text { Science, technology, and } \\
\text { society relationship }\end{array}$} & \multirow{4}{*}{$\begin{array}{l}\text { Relationship between } \\
\text { science and technology }\end{array}$} & $\begin{array}{l}\text { Science and technology are closely related } \\
(\mathrm{K} 1, \mathrm{~K} 4, \mathrm{~K} 5, \mathrm{~K} 7, \mathrm{~K} 10)\end{array}$ \\
\hline & & $\begin{array}{l}\text { Technology is the reflection of science } \\
(\mathrm{K} 5, \mathrm{~K} 7)\end{array}$ \\
\hline & & $\begin{array}{l}\text { Science enters our lives through technology } \\
\text { (K10) }\end{array}$ \\
\hline & & $\begin{array}{l}\text { Scientific research guides technological developments (K3, } \\
\mathrm{K} 4, \mathrm{~K} 5, \mathrm{~K} 7, \mathrm{~K} 10) \text {. }\end{array}$ \\
\hline
\end{tabular}


Technological developments lead to the development of scientific research

(K3, K4, K5, K7, K10)

There is no technology without science

(K1, K10)

Scientific knowledge varies depending on the characteristics of different societies and cultures

(K1, K3, K4, K5, K10,)

Impact of science on technology and society

The studies of scientists living in different countries are not the same because the development and needs of the countries are effective

$(\mathrm{K} 4, \mathrm{~K} 10)$

It also depends on the education that the scientist receives (K5)

\begin{tabular}{|c|c|}
\hline \multirow{5}{*}{$\begin{array}{l}\text { Impact of society on } \\
\text { science and technology }\end{array}$} & $\begin{array}{l}\text { Cultural values of society affect scientific studies } \\
(\mathrm{K} 1, \mathrm{~K} 4, \mathrm{~K} 10)\end{array}$ \\
\hline & $\begin{array}{l}\text { The economic level of the country affects scientific studies } \\
(\mathrm{K} 1, \mathrm{~K} 5, \mathrm{~K} 10)\end{array}$ \\
\hline & $\begin{array}{l}\text { Society has an impact on the work done in science and } \\
\text { technology } \\
(\mathrm{K} 1, \mathrm{~K} 6, \mathrm{~K} 7, \mathrm{~K} 10)\end{array}$ \\
\hline & $\begin{array}{l}\text { Cultural values of society affect scientific studies } \\
(\mathrm{K} 3, \mathrm{~K} 4, \mathrm{~K} 5, \mathrm{~K} 8)\end{array}$ \\
\hline & $\begin{array}{l}\text { It is the study done for the needs of society, for the benefit of } \\
\text { society } \\
(\mathrm{K} 3, \mathrm{~K} 4, \mathrm{~K} 8, \mathrm{~K} 10)\end{array}$ \\
\hline
\end{tabular}

The opinions of the teacher candidates on the relationship between science and technology are that science and technology are closely related, technology is a reflection of science, and science enters our lives with technology. "Science and technology are parallel, the more the science develops, the technology progresses with it" statement of K7 and "Science cannot be without technology, technology cannot be without science" statement of K9, reveal the relationship between science and technology.

In terms of the impact of science and technology on society, most candidate teachers believe that social and cultural structure affects science and technology. "Scientists reveal their studies in the society they live in by being influenced by their own culture. It uses technology as a tool also. The point of view of the scientist living in America or Egypt may be different due to the influence of the culture of their societies." statement of K6 is quite noteworthy. The cultural system of a country affects the results of scientists and the reason for this is that the subject scientists in different countries will work on is different in their studies according to the development levels and needs of the countries. Most of the teacher candidates stated that the culture and structure of the society in which scientific studies are conducted affect the scientist and scientific research.

In addition to the culture of the society in which the scientific study was conducted, the candidate teachers stated that the level of development of the country and its economy also influences the scientific study. "Developed societies are aware of science, they can contribute to science and can immediately benefit from the opportunities provided by science, but in undeveloped societies, science has developed in only limited areas which are used by a certain group of people." statement of $\mathrm{K} 3$, is noteworthy in this regard. 
They noted that science and technology affect society, and this effect can be positive, as well as cause negative consequences. They noted that the positive effects of science and technology on society have benefits in areas such as making life easier, raising the welfare level of people, society, transportation, communication. They stated that, due to the negative effects of science and technology, people are drifting away from social life due to excessive use of the internet and phone usage, as well as a decrease in the number of visits to relatives.

\section{Discussion}

According to the results obtained from the study, teacher candidates have misconceptions about science. "Experiment is the only way for scientific research, social sciences are not a field of science, and definition of science as an invention", statements from the teacher candidates, show that some teacher candidates have misconceptions about science.

According to the content of science, some of the teacher candidates do not consider social science fields such as history, geography as a science, because they believe that knowledge of these fields cannot be proven. Considering that the field of social studies is also included in the social sciences, it is an important result that the teacher candidates do not accept their field as a science. This conclusion is also supported by the results of other studies in the literature that examine the views of teacher candidates on science (Abd-El-Khalick \& BouJaoude, 1997; Chen, 2001; Tairab, 2001; Doğan, 2005; Er, 2017; Sönmez \& Pektaş, 2017; Kesgin \& Timur, 2020; Turgut \& Yakar, 2020; Yakmacl, 1998). The fact that some of the teacher candidates expressed the purpose of science as a new invention, and designing technological tools showed that they confused science and technology. This result is similar to many previous study results (Yakmac1, 1998; Erdoğan, 2004; Kahyaoğlu, 2004; Doğan Bora, 2005; Turgut, 2005; Çınar \& Köksal, 2013; Pala \& Başı̈üyük, 2020). In his study with science teacher candidates, Turgut (2005) stated that teacher candidates were confused when defining science and technology. Teacher candidates have said that science can have positive and negative consequences. It is noteworthy that all of the teacher candidates gave the atom bomb example to the negative consequences of science.

Teacher candidates expressed technology as tools that make human life easier (computers, internet, electronic devices, and machines). Teacher candidates have identified computers, the internet, or electronic devices as technology. These statements are similar to studies in the literature (Ryan \& Aikenhead, 1992; Volk \& Dugger, 2005; Yalvaç, Tekkaya, Çakıroğlu \& Kahyaoğlu, 2007; Yiğit, 2011; Akgün \& Akgün, 2020; Özer, Kiray \& Çardak; 2020; Yürektürk \& Coşkun, 2020). Most of the teacher candidates see the health effects of technology as a disadvantage.

In terms of the relationship between science, technology, and society, most of the teacher candidates think that the social and cultural structure affects both science and technology and that it is affected by science and technology. There are studies supporting this view (Zeidler, Walker, Ackett, \& Simmons, 2002; Y1lmaz, 2014; Er, 2017; Kabatas Memis \& Ezberci Cevik, 2017; Benzer, 2020; Özer, Kıray \& Çardak, 2020). Teacher candidates ' views that technology significantly affects society's value judgments are similar to other research results in the literature (Yiğit, Çengelci, \& Karaduman, 2013). They also noted that countries' levels of development, levels of prosperity, and economies also affect scientific and technological work.

\section{Conclusion}

This study was conducted to determine social studies teacher candidates' views on science, technology, and society. Interview technique was used in qualitative research methods in the study conducted with 10 social studies teacher candidates. As a result of the interviews, in line with the information in the literature, the opinions of the teacher candidates about science, technology, and society were examined under science, technology, and the relationship between science and technology. 
The views of teacher candidates about science were examined in terms of the content of science, the aim of science, and the scientific method. In terms of the content of science, some teacher candidates considered social fields such as history and geography as science fields, while some teacher candidates stated that they did not accept these fields as a science because they believe that knowledge of these fields cannot be proven.

In terms of the purpose of science, some teacher candidates express science as making life easier and revealing the facts, while others think that it is malicious or harmful to humanity and society. All of the teacher candidates gave the atom bomb example to the malicious use of science. It is also seen that during the definition of science, some of them expressed the purpose of science as inventing things, designing technological products. From these statements, it can be said that candidate teachers confuse science and technology.

In the method of science category, some teacher candidates stated that the experiment is necessary for proving, while some teacher candidates stated that the experiment is not the only method.

Teacher candidates have defined technology as tools and electronics that make life easier. They expressed the advantage of technology as making human life easier, and its disadvantage is its harm to health.

Most of the teacher candidates think that socio-cultural structure affects scientific knowledge. They also stated that the culture and structure of the society in which scientific studies are conducted affect the scientist and scientific research. In addition to the culture of the society in which the scientific study was conducted, the candidate teachers stated that the level of development of the country and its economy also influences the scientific study.

\section{Recommendations}

In line with the results of this study, activities can be organized to eliminate the misconceptions of social studies teacher candidates about science and technology. Example situations and activities can be created with social studies teacher candidates related to the social effects of science and technology. The Science, Technology and Society course in the social studies teaching program is appropriate in terms of being a course in which the social effects of science and technology will be discussed. Within the scope of this course, classroom activities, and practices that cover the social dimensions of science and technology can be conducted with teacher candidates. Course activities can be prepared covering the characteristics of science, the development of scientific knowledge, and the relationship between science and technology with society.

Conducting the courses in the social studies teaching program with a focus on science-technologysociety issues will increase the awareness and knowledge of pre-service teachers by making discussions on these topics. 


\section{REFERENCES}

Abd-El-Khalick, F., \& BouJaoude, S. (1997). An exploratory study of knowledge base for science teaching. Journal of Research in Science Teaching, 34(7), 673-699. https://doi.org/10.1002/(SICI)10982736(199709)34:7<673::AID-TEA2>3.0.CO;2-J

Akgün, İ. (2015). Investigation of 7th grade students' level of achievement on the science, technology and society learning space in social studies in terms of some variables. International Journal of Turkish Literature Culture Education, 4 (2), 770-782. http://dx.doi.org/10.7884/teke.480

Akgün, İ. H., \& Akgün, M. (2020). Sosyal bilgiler öğretmen adaylarının dijital okuryazarlık düzeylerinin incelenmesi. Kırşehir Eğitim Fakültesi Dergisi, 21(2), 1006-1024.

American Association for the Advancement of Science (AAAS). (1990). Project 2061: Science for all Americans. New York, Oxford: Oxford University Press.

Ata, B. (2017). Bilim, teknoloji ve sosyal değişme. B. Ata (Ed.). Bilim ve Teknolojinin Sosyal Değişmeye Etkisi. (s.311). Ankara: Pegem Akademi.

Bağcı-Kılıç, G., Haymana, F., \& Bozyılmaz, B. (2008). İlköğretim fen ve teknoloji dersi öğretim programının bilim okuryazarlığı ve bilimsel süreç becerileri açısından analizi. Eğitim ve Bilim, 33(150), 52-63.

Benzer, E. (2020). Bilïmsel okuryazarlik ve medya okuryazarliği arasindakï ilişkï: Fen bilgïsï öğretmen adaylari örneği. Araştırma ve Deneyim Dergisi, 5(1), 10-23.

Bybee, R. W. (1997). Achieving scientific literacy: From purposes to practices. Portsmouth: Heinemann.

Chen, S. (2001). Prospective teachers' views on the nature of science and science teaching. (Unpublished Doctoral Dissertation) Indiana University, Indiana, USA

Creswell, J. W. (2013). Research design: qualitative, quantitative, and mixed methods approaches. New York: Sage.

Çakıc1, Y. (2012). Exploring Turkish upper primary level science textbooks' coverage of scientific literacy themes. Eurasian Journal of Educational Research, 49, 81-102.

Çepni, S., Ayvacı, H. Ş., \& Bacanak, A. (2009). Bilim teknoloji toplum ve sosyal değişim. Trabzon: Çelepler Matbaacilık.

Çepni, S., \& Bacanak, A. (2002). A study on determining mathematics student teachers' scientific literacy, paper presented at the meeting of the changing times, changing needs. First International Conference on Education Faculty of Education Eastern Mediterranean University, May 8-10, Gazimagusa, Turkish Republic of Nothern Cyprus.

Çınar, M., \& Köksal, N. (2013). Sosyal bilgiler öğretmen adaylarının bilime ve bilimin doğasına yönelik görüşleri. Mersin Üniversitesi Ĕ̆itim Fakültesi Dergisi, 9(2), 43-57.

Doğan, B. N. (2005). In Turkey, the investigation of views on the nature of science branch of high school science teachers and students. (Unpublished master's thesis) Gazi University, Ankara, Turkey.

Duban, N. (2010). Sınıf öğretmeni adaylarının fen ve teknoloji okur-yazarı bireylere ve bu bireylerin yetiştirilmesine ilişkin görüşleri. Kuramsal Ĕ̆itimbilim Dergisi, 3(2), 162-174.

Er, H. (2017). A sample application for use of biography in social studies; science, technology and social change course. Journal of Education and Training Studies, 5(5), 156-170. 
Erdoğan, R. (2004). Investigation of the preservice science teachers' views on nature of science. (Unpublished master's thesis) Middle East Technical University, Ankara, Turkey.

Gültekïn, M. (2020). Değişen toplumda eğitim ve öğretmen nitelikleri. Anadolu Journal of Educational Sciences International, 10(1), 654-700. https://doi.org/10.18039/ajesi.682130

Holbrook, J., \& Rannikmae, M. (Eds.). (1997). Supplementary teaching materials promoting scientific and technological literacy. Tartu, Estonia: ICASE (International Council of Associations for Science Education).

Hurd, P. D. (2000). Science education for the 21st century. School Science and Mathematics, 100(6), 282-288. https://doi.org/10.1111/j.1949-8594.2000.tb17321.x

Jan, H. (2017). Teacher of $21^{\text {st }}$ century: Characteristics and development. Research on Humanities and Social Sciences 7(9), 50-54.

Kabatas Memis, E., \& Ezberci Cevik, E. (2017). Examination of students' small groups discussion in argumentation process: Scientific and socio-scientific issues. Journal of Education in Science, Environment and Health, 3(2), 126-137. https://doi.org/10.21891/jeseh.325788.

Kalyon, D. Ş. (2020). Adaptation of scientific literacy skill test to Turkish. Kastamonu Education Journal, 28 (5), 2019-2043.

Kahyaoğlu, E. (2004). Turkish preservice science teachers' views on sts: characteristics of scientists' work. (Unpublished Master's Thesis) Middle East Technical University, Ankara, Turkey.

Kaymakçı, S. (2010). Yeni sosyal bilgiler programı ve ders kitaplarının bilim ve teknolojiye yaklaşımı. B. Ata (Ed.) Bilim teknoloji ve sosyal değişme (pp. 13-38). Ankara: Pegama Yay.

Kesgin, D., \& Timur, B. (2020). Öğretmen adaylarının bilimin doğasına yönelik görüşleri. Eğitim ve Toplum Araştırmaları Dergisi, 7(1), 270-299.

Kolstø, S. D. (2006). Patterns in students' argumentation confronted with a risk-focused socio-scientific issue. International Journal of Science Education, 28(14), 1689-1716. https://doi.org/10.1080/09500690600560878

Laugksch, R. C. (2000). Scientific literacy: a conceptual overview. Science Education, 84, 71-94.

Lederman, N., Abd-El-Khalick, F., Bell, R. L., \& Schwartz, R. S. (2002). Views of nature of science questionnaire: Toward valid and meaningful assessment of learners' conceptions of nature of science. Journal of Research in Science Teaching, 39(6), 497-521. https://doi.org/10.1002/tea.10034

McComas, W. F. (1998). The principle elements of the nature of science: Dispelling the myths. In W.F. McComas (Eds.). The nature of science in science education: Rationales and strategies (pp. 53-70). Dordrecht: Kluwer Academic Publishers.

Merriam, S. (2009). Qualitative research: a guide to design and implementation. San Francisco: CA: Jossey Bass.

Miles, M., \& Huberman, A. (1994). Qualitative data analysis. Londra: Sage Pub.

Milli Eğitim Bakanlığı[Ministry of National Education] (2014) Milli Eğitim Bakanlığı Talim ve Terbiye Kurulu Başkanlığı. İlköğretim Sosyal Bilgiler Dersi Programı [Primary Education Social Studies Curriculum]. Ankara: MEB Yayınları 
Milli Eğitim Bakanlığ1 [Ministry of National Education] (2016). İlköğretim sosyal bilgiler 6.sınıf eğitim programı ve klavuzu [Primary education social studies 6th grade education program and manual]. Ankara: MEB Yayınları.

Milli Eğitim Bakanlığ1 [Ministry of National Education] (MEB) (2019). Sosyal bilgiler dersi öğretim programı (ilkokul ve ortaokul 4, 5, 6 ve 7. siniflar) [Social studies lesson curriculum (primary, and secondary school 4th, 5th, 6th and 7 th grades)]. Ankara: MEB Yayınlar1.

National StandFarts for Social Studies-NCSS (2010). The themes of social studies. Retrieved September 01, 2020 from http://www.socialstudies.org/standards/strands.

National Research Council [NRC]. (1996). National science education standards. Washington, DC: National Academy Press.

National Research Council. (2004). How people learn: Bridging research and practice. Washington, DC: National Academy Press.

National Science Education Standards (1996). National academy of sciences. Washington DC: National Academy Press.

National Science Teachers Association [NSTA]. (2003). Standards for science teacher preparation. Retrieved September 01, 2020 from http://www.nsta.org/pdfs/NSTAstandards2003.pdf.

Organisation for Economic Cooperation and Development. (2007). Assessing scientific, reading and mathematical literacy: A framework for PISA 2006. Retrieved September 11, 2020 from http://www.oecd.org/dataoecd/63/35/37464175.pdf

Organisation for Economic Cooperation and Development. (2003). The PISA 2003 assessment framework. Retrieved September 11, 2020 from http://www.pisa.oecd.org/dataoecd/ 46/14/33694881.pdf

Özdemir, S. M. (2011). Education and curricula within the context of social change and globalization: a conceptual analysis. Ahi Evran University Journal of Kırşehir Education Faculty, 12(1), 85-110.

Ozer, S., Kıray, S. A., \& Cardak, O. (2020). Science teacher candidates' views about science-technology-society environment relations. Eurasian Journal of Educational Research, 91, 83-104.

Pala, Ş., \& Başıüyük, A. (2020). Ortaokul beşinci sınıf öğrencilerinin sosyal bilgiler dersi bilim teknoloji ve toplum öğrenme alanına ilişkin akademik başarılarının incelenmesi. Milli Eğitim Dergisi, 49(228), 301334. https://doi.org/10.37669/milliegitim.631709

Patton, M. Q. (2005). Qualitative research. New York: John Wiley \& Sons, Ltd.

Ryan, A. G., \& Aikenhead, G. S. (1992). Students' preconceptions about the epistemology of science. Science Education, 76, 559-580. https://doi.org/10.1002/sce.3730760602

Sadler, T. D., \& Zeidler, D. L. (2005). Patterns of informal reasoning in the context of socio scientific decision making. Journal of Research in Science Teaching, 42(1), 112-138. https://doi.org/10.1002/tea.20042

Sönmez, E., \& Pektaş, M. (2017). The effects of some activities of biotechnology in extra-curricular on middle school students nature of science perceptions and biotechnology knowledge. Kastamonu Ĕ̆itim Dergisi, 25(5), 2019-2036.

Şahin, C. T., \& Say, Ö. (2010). İlköğretim öğrencilerinin bilimsel okuryazarlik düzeylerinin incelenmesi. Uluslararası Yönetim İktisat ve İşletme Dergisi, 6(11), 223-240. 
Şahïn, C. T. (2017). Sosyal bilgiler öğretmen adaylarının bilimsel okuryazarlıklarının geliştirilmesi: eylem

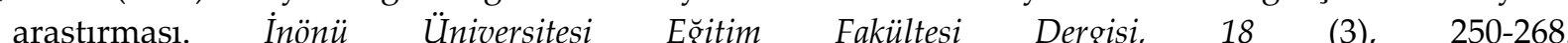
https://doi.org/10.17679/inuefd.369225

Strauss, A., \& Corbin, J. M. (1990). Basics of qualitative research: Grounded theory procedures and techniques. USA. Sage Publications, Inc.

Tairab, H. H. (2001). How do pre-service and in-service science teachers view the nature of science and technology? Research in Science and Technological Education, 19(2) 235-250. https://doi.org/10.1080/02635140120087759

Turgut, H. (2005). Yapılandırmacı tasarım uygulamasının fen bilgisi öğretmen adaylarının bilimsel okuryazarlık yeterliklerinden "bilimin doğası" ve "bilim-toplum-teknoloji ilişkisi" boyutlarmnn gelişimine etkisi [The effect of constructivist design application on the development of "nature of science" and "science-society-technology relationship" dimensions of science teacher candidates' scientific literacy competencies]. (Unpublished Master's Thesis) Yıldız Technical University Graduate School of Social Sciences, Istanbul, Turkey.

Turgut, D., \& Yakar, Z. (2020). Does teacher education program affect on development of teacher candidates' bioethical values, scientific literacy levels and empathy skills? International Education Studies, 13(5), 8093.

Volk, K. S., \& Dugger, W. E. (2005). East meets west: What Americans and Hong Kong people think about technology. Journal of Technology Education. 17(1), 53-68.

Yalvaç, B., Tekkaya, C., Çakıroğlu, J., \& Kahyaoğlu, E. (2007). Turkish preservice science teachers' views on science-technology- society issues. International Journal of Science Education, 29, 331-348. https://doi.org/10.1080/09500690600708667

Yakmaci, B. (1998). Science (biology, chemistry and physics) teachers' views on the nature of science as a dimension of scientific literacy. (Unpublished Master's Thesis) Boğaziçi University, Istanbul, Turkey.

Yilmaz, A. S. (2014). Entrepreneurship education as a social changing agent. Journal of World of Turks. 6(1), 297310.

Yiğit, E. Ö. (2011). Sosyal bilgiler öğretmen adaylarının teknoloji okuryazarlı̆̆ı düzeylerinin ve teknoloji ile bütünleştirilmiş sosyal bilgiler öğretimine yönelik görüşlerinin belirlenmesi [Determining the technology literacy levels of social studies teacher candidates and their views on social studies integrated with technology]. (Unpublished Master's Thesis) Marmara University Institute of Educational Sciences, Istanbul, Turkey.

Yiğit, E. Ö., Çengelci, T., \& Karaduman, H. (2013). Pre-service social studies teachers' views about reflection of technology on values. Journal of Social Studies Education Research, 4(1), 73-96.

YÖK/Dünya Bankası Milli Eğitimi Geliştirme Projesi [YÖK / World Bank National Education Development Project]. (1997). Illköğretim sosyal bilgiler öğretimi [Elementary social studies education]. Ankara, Turkey

YÖK. (2018). Öğretmen yetiştirme lisans programları [Teacher Training Undergraduate Programs]. Ankara: YÖK $\begin{array}{lllll}\text { yayını. } & \text { Retrieved } & \text { September } & 2020 & \text { from }\end{array}$ https://www.yok.gov.tr/Documents/Kurumsal/egitim_ogretim_dairesi/Yeni Ö̈ğretmen-YetistirmeLisans Programlari/AA_Sunus_\%20Onsoz_Uygulama_Yonergesi.pdf.

Yüksek Öğretim Kurumu [Council of Higher Education] (YÖK) (2019). Yeni Öğretmen Yetiştirme Lisans Programlar [New Teacher Training Undergraduate Programs], Retrieved September 1, 2020 from https://www.yok.gov.tr/kurumsal/idari-birimler/egitim-ogretim-dairesi/yeni-ogretmen-yetistirmelisans-programlari 
Yürektürk, F., \& Coşkun, H. (2020). Türkçe öğretmenlerinin teknoloji kullanımına ve teknoloji destekli türkçe öğretiminin etkililiğine dair görüşleri. Ana Dili Eğitimi Dergisi, 8(3), 986-1000. https://doi.org/10.16916/aded.748300

Zeidler, D. L., Walker, K. A., Ackett, W. A., \& Simmons, M. L. (2002). Tangled up in views: Beliefs in the nature of science and responses to socioscientific dilemmas.Science Education, 86(3), 343-367. 